\title{
Teaching Work: Emotions and Affections in an Instruction to the Double Experience
}

\author{
Siderlene Muniz-Oliveira \\ Doctor in Applied Linguistics \\ Federal University of Technology (UTFPR) \\ Paraná State, Brazil \\ Câmpus Dois Vizinhos, Câmpus Pato Branco
}

\begin{abstract}
In this paper, we present results about emotions and affections in texts produced for a doctoral thesis. As theoretical framework, our research is based, mainly, on disciplines which study working situations, as Labor Psychology, particularly, the Activity Clinic besides the language concept comes from a dialogical perspective that considers the dialogue as an engine of the development. To the text under analysis we employed a method called instruction to the double with an experienced professor of the field of language studies. Through this method, she lived an experience providing the researcher instructions on how to perform her teaching work activities. In this experience, the professor emotions are emerged in instruction to the double interaction. Results show emotional and affective aspects represented in the analyzed texts about this work situation experience, what lead to a better understanding and comprehension of teacher/professor teaching learning process.
\end{abstract}

Keyword: Activity Clinic; teaching work; personal dimension; emotions.

\section{Introduction}

In this paper, we present the results of an analysis carried out in a text produced by an English language teacher as a foreign language of a Brazilian public university that had as its theme the work of the teacher. Thus, the specific objective of this paper is to identify affections and emotions, represented in this text referring to the work of such teacher.

We start from theoretical and methodological assumptions both of Labor Psychology called Activity Clinic, which developed a method called instruction to double that makes possible a dialogue about the work that we use in this research; and of Sociodiscursive Interactionism, which will contribute to the categories of analysis, as will be presented in the methodology section.

Then, we address the central assumptions underlying this work.

\section{Theoretical Assumptions}

As theoretical and methodological assumptions, we used the concept of language derived from a dialogic approach (Voloshinov, 1997), which considers dialogue as the engine of development, allied to Labor Psychology references, in specific the Activity Clinic's ones (Clot, 2006, 2010, 2016).In a central way, we start with vygotskian assumptions that, in developing their theory of consciousness, connect, in the activity, the subject's thought, language and emotions (Clot, 2006; Vygotsky, 1994).Aiming to make a study about the emotions, we start from the assumptions of the Activity Clinic (Clot, 2006, 2010), which is a current of Labor Psychology, which addresses the problem of subjectivity.Situated in the Activity Clinic, Clot $(2006,2010,2016)$ studies the issues related to affections and emotions starting from a vygotskian perspective. For Clot (2016, p.90-91), although both belong to affectivity, affection and emotion are not the same thing, as can be seen in the following. "We start with two quotations from Spinoza: the first is at the beginning of the Ethics: "I call affection what increases or decreases the power of acting". Here we have a definition of affection as a transformer, work force, activity development. Put in another way, affection has to do with action."(Clot, 2016, p.90-91; author's emphasis, our translation).In the case of emotion, Clot (2010, p.6) clarifies that emotion is not only an intensive aspect of cognition, but it also involves the sense of an activity that is affected or disaffected by the other or by the subject itself. 
Clot (2010), citing Zapf (2002), affirms that the positive or negative emotions experienced depend on the sense given by the worker to the emotional pressure assumed when developing his/her work task, being therefore intrinsically dependent on the work situation experienced. Yet according to Clot (2016, p. 90), the emotions are corporeal, being the voice a good object of study, because the voice belongs to words, to language, with intonations and accents.Starting from the perspective of the Activity Clinic, Machado (2007) deals with the dimensions of the teacher's work, which are the personal, impersonal, interpersonal, transpersonal dimensions. For this research, it is important to understand the personal dimension of teaching work, which is fully related to emotions.

The personal dimension involves the whole of the worker's dimensions (the physical, the mental, the emotional, the affective etc). In this sense, the teacher engages physically, mentally, emotionally and affectively to the accomplishment of his/her work activity, mobilizing his/her integral being.In this work, we identified affections and emotions, represented in the analyzed text about the work of the English language teacher as a foreign language, which are part of the personal dimension. The Activity Clinic proposes some methods that bring up the dialogue, that is, the interaction for the analysis of the work, being the instruction to the double the method that we used in this research, as we will see next.

\section{Methodology}

As a method of production of the analyzed texts, we used a type of interaction / dialogue called instruction to the double developed by researchers of the Labor Psychology in the Activity Clinic of the Conservatoire National des Arts et Métier (CNAM) (Clot, 2006, 2010) in Paris. From the instruction to the double, the researcher places himself/herself in a fictitious situation, assuming that he/she will replace the worker in his/her work, so that he/she must give directions and instructions to the researcher (the double) for the adequate development of the work (Muniz- Oliveira, 2015).The author of this paper played the role of researcher and the double. The instructor was an experienced teacher of English as a foreign language in one of the most renowned Brazilian institutions called Universidade de São Paulo (USP) located in the state of São Paulo, Brazil.The instruction to the double was recorded and then the oral text was transcribed, following norms of transcription (Koch, 1997). For the analysis, we used the transcribed text. The guidelines of ethics committee were followed and approved by the number process CAAE 33987814.6.0000.5547 of PlataformaBrasil (Brazil)

Regarding the categories of analysis, some linguistic-discursive phenomena were observed and some categories revealing the personal dimension were identified, being used as category of analysisa) expressions that reveal evaluations about the teaching action or situation related to student action; b) the identification of direct speech (E.g.: She said / spoke) and what they indicate, and c) first-person possessive pronoun that emphasize the teaching action of the professor (Muniz-Oliveira, 2015).Considering the extension rules of this work, we selected just three elements to discuss phenomena observed in the text, revealing affection and emotion in the work of the language teacher. As the text analyzed is in Portuguese language, for the better understanding of the reader the original excerpts are in the Supplementary Material in the end of this paper.

\section{Analysis Results}

Firstly, in the section below, we observe the occurrence of direct speech expressed with an interjection. According to Tomazeto (2012), interjection is a:

"Word that translates, in a living way, the states of soul. It is a real key word in which the speaker, imbued with emotion, tries to express his psychic state at a sudden moment, instead of expressing himself by a logically organized phrase" (Câmara Jr. 1977, p. 147 apudTomazeto, 2012, p.8, our translation).

According to the author, the interjection expresses strongly an emotion, "the states of soul" (Tomazeto, 2012) and, in our view, its interpretation totally depends on the context and the intonation. In the section below, the interviewed professor was giving instructions on how to act with graduate students who have difficulties writing their final scientific work. She gave an example of two student's cases. In one of them, the professor advised the student (her advisee) to do therapy. Then the professor states:

309Professori: Yes, she had an existential problem that was disturbing her. Then, when she told me, I said, "Ah...really?", this student is, she says she is... she seems to be going back on track. The other I don't know if... she needs, because she always ran away, and I now "No...I'm going to talk to you a little" (inaudible).

We highlight the part "I said'Ah... really" in which the professor expresses her emotion by using an interjection. 
In this case, we considered that the professor, by reviving a work situation, feels affected negatively, and revives a situation in which she was worried about her advisee's academic work, who on a certain day, told she had an existential problem that was hindering the development of her research. The professor by expressing "Ah...really?" shows, by interjection, representations of the feeling of amazement and surprise that she had to hear the student's revelation, which reveals the emotion felt.

Secondly, in the section below the analysis refers to the identification of expressions that reveal evaluation about student action in an excerpt that was discussed an issue related to students who would present difficulties not only referring to grammatical problems of textual writing, but also referring to the articulation of ideas due to the difficulty of understanding theories. Thus, we observed that the professor uses the repetition of the word "serious".

101Researcher: Right, and if it is like this, not only language problems...these little superficial problems, but if there are problems of idea, of articulation... of ideas, that you are realizing that they are not understanding the theories, right? They are not being able to articulate the ideas, that they are having difficulties of comprehension.

\section{Professor: Then it is serious.}

103Researcher: Hum. With the fundamental assumptions.

103Professor: Then it is serious. It is serious. You try to point them. But you will not be able to resolve if they don't resolve. The person is the one who has to want and perceive.There are two cases, I have already gone through this experience more than once.

The previous section (101R) deals with a hypothetical case, brought by the researcher, referring to a student who would have serious problems when writing his/her final post-graduate work (master's or doctoral degree). The teacher, from the use of "That's serious", expresses a negative evaluation of the situation referring to student textual writing. We observed that the professor repeats three times the word "serious" in "Then it is serious" referring to an experience, in fact, lived by her: "I have already gone through this experience more than once". We comprehend serious as something that indicates symptoms of dangerous nature and then requires attention.

This repetition maybe reveals an anguish related to some obstacle lived previously that, in the same way, would make evident in the speech this difficulty to the expression of "wanting to say" of the professor, trying to put into words this lived situation.

Thirdly, we identified a first-person pronoun that caught our attention, as we can observe in the section below, referring to a moment in which was approached the fact that the professor conducts an unofficial seminar of research for the advisees. The discipline was not registered in the university's courses system.

218Professor: But here the number of credits required is not so high, so we have that freedom. The only problem is that there is no institutional recognition of $M Y$ work $^{\mathrm{ii}}$. For the students it is great. [...] 226Professor: [...] But there is no recognition because then he [the boss] is going to say "How many classes does she teach a week?" The number of classes is low, right?[...]

241Professor: (Laughs) I will try to solve it.

The use of first-person pronoun shows the teacher considers her own teaching action. Which aroused attention for the analysis was the intonation ${ }^{\text {iii }}$ that is one of the means "through which the voice translates the affective and emotional states" (Britoet al, 2007, p.20, our translation). Depending on the intonation, a word can be expressed in different ways, provoking different emotions ${ }^{\text {iv }}$.

The use of the pronoun "My" with high intonation reveals that the professor feels affected in dealing with this subject in which she herself perceives that there is no recognition of her work, in this case she feels the need to emphasize (such as the use of first-person possessive pronoun) that the activity of research seminar taught by her is not recognized. For Clot (2010), in work situations, recognition by the other is a fundamental aspect. According to this author (Clot, 2010, p. 284, author's emphasis; our translation), "The symbolic 'retribution' and the 'gratifications' associated with it, coming from the hierarchy, make useful the one who works; in addition, the judgment of the peers is what grants profession membership". Perhaps the instruction to the double allowed the professor to become aware of the non-recognition of her work evidenced by the expression "I will try to solve it" in $241 \mathrm{P}$. Thus, the intonation in the first-person possessive pronoun shows that the non-recognition negatively affects the professor. 


\section{Final considerations}

The results show some linguistic-discursive elements that demonstrate moments in which the professor is affected when reviving situations of her work, revealing some emotions, for example, when there is alteration in her voice, in the case of emphatic intonation.We observed, in the sections discussed, that negative emotions are highlighted in analyzes. We believe that this fact may be directly related to the selected method, the instruction to the double, that is a method in which we must "focus on possible problems or difficulties for the performance of a [job] task"(Muniz-Oliveira, 2015, p.165, our translation).

${ }^{\mathrm{i}}$ The text in original language is in the Supplementary Material.

ii The professor refers to the fact of conducting a course that is not registered in the university's system.

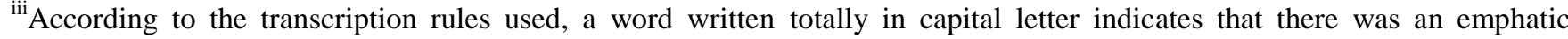
intonation when a word was pronounced.

${ }^{i v}$ Available on: www.hcrp.usp.br/sitehc/upload\%5CVoz\%20e\%20emoção.doc Accessed on Oct. 14, 2017.

\section{References}

Brito, C. M. P. et al. (2007). Entoação: conceitos, modelos e perspectivas múltiplas. In: Aguiar, M. A. M.;Madeiro, F. (Orgs). Em-TOM-ação: a prosódia em perspectiva. Editora Universitária, UFPE.

Clot, Y. (2006). A função psicológica do trabalho.Translator: Adail Sobral. Petrópolis, RJ: Vozes.

Clot, Y. (2010).Trabalho e poder de agir.Translator: Guilherme João de Freitas Teixeira e Marlene Machado Zica Vianna. Belo Horizonte: Fabrefactum.

Clot, Y. (2016). A interfuncionalidade dos afetos, das emoções e dos sentimentos: o poder de ser afetado e o poder de agir. In: Banks-Leite, L.; Smolka, A. L. B.; Anjos, D. D. (orgs). Diálogo na perspectiva históricocultural: interlocuções com a clínica da atividade. Mercado de Letras: Campinas-SP, pp. 87-95.

Koch, I. (1997). A inter-ação pela linguagem. 3. ed. São Paulo: Contexto.

Machado, A. R. (2007). Por uma concepção ampliada do trabalho do professor. In: Guimarães, Ana Maria de Mattos; Machado, Anna Rachel, Coutinho, Antónia (organizadoras). $O$ InteracionismoSociodiscursivo:questões epistemológicas e metodológicas. São Paulo: Mercado de Letras, pp. $77-97$.

Muniz-Oliveira, S. (2015). O trabalho docente no ensino superior: múltiplos saberes, múltiplos fazeres do professor de pós-graduação- Campinas, SP: Mercado de Letras.

Tomazeto, S. A. (10/2012). As interjeições nas "tiras em quadrinhos: uma reflexão semântico-pragmática.Revista Vozes dos Vales da UFVJM: Publicações Acadêmicas - MG - Brasil - Nº 02 - Ano I.

Voloshinov, V. N. (1997). Marxismo e filosofia da linguagem. Translator : Michel Lahud e Yara Frateschi Vieira. 10. ed. São Paulo: Hucitec.

Vygotsky, L. (1994). Le problème de la conscience dans la pychologie du comportement. Translator: F. Sève. SociétéFrançaise, 50, 35-47.

\section{Supplementary Material}

Excerpts in original language - Portuguese

309Professora: É, ela tinha problema existencial que estava perturbando. Aí quando ela contou, eu falei "Ah...né” uma está, diz que está...parece que está entrando no eixo. A outra não sei se... precisa porque ela sempre fugiu, e eu agora "não", eu vou falar com você um pouco (inaudível).

101Pesquisadora: Certo, e se tiver assim, não só problemas de língua...esses probleminhas aí mais superficiais, mas se tiver problemas de ideias, de articulação... das ideias, que você está vendo que ele não está compreendendo as teorias, né, não tá conseguindo articular as ideias, que ele está com dificuldade mesmo de compreensão.

102Professora: Aí é grave.

103Pesquisadora: Hum. Com os pressupostos fundamentais.

104Professora: Aí é grave. Aí é grave. Você tenta apontar. Mas você não vai conseguir resolver se ele não resolver. A pessoa que tem que querer e perceber. Tem dois casos, eu já passei por essa experiência mais de uma vez.

218Professora: Mas aqui o número de créditos exigido não é tão alto, então a gente tem essa liberdade. O único problema é que não existe um reconhecimento institucional do MEU trabalho. Para os alunos é ótimo

226Professora: [...] Só que não existe reconhecimento porque daí ele [chefe] vai dizer "Quantas aulas ela dá por semana?” O número de aulas é baixo né?

241Professora: (Risos) Eu vou tentar resolver isso. 